\title{
More fruits and vegetables!
}

The World Health Organization, WHO, has recently released its reports on its strategy of cooperation with countries in the next five years.

These reports all emphasize the increasingly heavy burden of noncommunicable diseases, NCDs, in Africa, such as cardiovascular disease, hypertension, cancer, diabetes and obesity, which are becoming serious public health problems. As examples, the NCDs in Ethiopia accounted for approximately 30.6\% of all deaths in 2005 and could reach 43.2\% in 2030; in Dakar, Senegal, the number of new diabetes cases has risen from 200 per year in 1980 to over 2000 per year today; in South Africa, cardiovascular diseases were the leading cause of death in 2000; in Kenya, the prevalence of diabetes has increased from 1 to $3.3 \%$ of the population over the past decade, reaching $10 \%$ in urban areas, while, in Mauritius, the NCDs represent $75 \%$ of the total burden of disease.

In all these countries, the availability of fruits and vegetables is below, often far below, the minimum consumption level recommended by the WHO. In addition, these products are not easily accessible to poorer consumers because their prices are generally too high. It is now well recognized that a low consumption of fruits and vegetables is a high risk factor for NCDs, in addition to other risk factors such as changing lifestyles, pollution and physical inactivity, especially in urban areas. In addition to deficiencies in micronutrients, vitamin $\mathrm{A}$ and $\mathrm{Fe}$ in particular, which are present in fruits and vegetables, the second burden of NCDs is emerging very rapidly, especially among the poorest urban areas, where more than half of the world's population will live very soon.

It is time that policymakers and donors became aware of these alarming tendencies concerning hidden hunger and for which solutions are known; such as, in particular, improving the consumption of fruits and vegetables. In this perspective, it would be necessary to mobilize key stakeholders from different sectors of horticulture, health and education at local and global levels, bearing in mind that biofortification and dietary supplements, which are too often seen as the only solution, will not be able to cope with this double burden.

Dr. Jacky Ganry Scientific Director of Fruits 


\section{Plus de fruits et légumes !}

L'Organisation mondiale de la santé, l'OMS, a récemment publié les rapports sur sa stratégie de coopération avec les pays au cours des cinq prochaines années.

Ces rapports soulignent tous le fardeau de plus en plus lourd des maladies non transmissibles, MNTs, en Afrique, comme les maladies cardiovasculaires, l'hypertension, le cancer, le diabète, l'obésité, qui sont devenus de sérieux problèmes de santé publique. A titre d'exemples, les MNTs en Éthiopie ont représenté environ 30,6 \% de tous les décès en 2005 et pourraient atteindre 43,2\% en 2030 ; à Dakar, au Sénégal, le nombre de nouveaux cas de diabète est passé de 200 par an en 1980 à plus de 2000 par an aujourd'hui ; en Afrique du Sud, les maladies cardiovasculaires étaient la principale cause de décès en 2000 ; au Kenya, la prévalence du diabète est passée de 1 à $3,3 \%$ de la population au cours des dix dernières années, atteignant $10 \%$ dans les zones urbaines, tandis qu'à l'île Maurice les MNTs représentent $75 \%$ du fardeau total de la maladie.

Dans tous ces pays, la disponibilité des fruits et légumes est en dessous, souvent bien au-dessous, du niveau de consommation minimum recommandé par l'OMS. En outre, ces produits ne sont pas facilement accessibles aux consommateurs les plus pauvres du fait de leurs prix généralement trop élevés. Il est main- tenant bien reconnu qu'une faible consommation de fruits et légumes est un facteur de risque élevé pour les MNTs, en plus des autres facteurs de risque tels que les nouveaux modes de vie, la pollution, l'inactivité physique en particulier dans les zones urbaines. En plus de carences en micronutriments, vitamine A et fer, en particulier, qui sont présents dans les fruits et légumes, le second fardeau des maladies non transmissibles est en train d'émerger très rapidement, en particulier parmi les populations les plus pauvres des zones urbaines, où plus de la moitié de la population mondiale vivra très bientôt.

Il est temps que les décideurs et les bailleurs de fonds prennent conscience de ces tendances alarmantes concernant la faim cachée et pour lesquelles des solutions sont connues, telles que, notamment, l'amélioration de la consommation de fruits et légumes. Dans cette perspective, il serait nécessaire de mobiliser les principaux intervenants de différents secteurs de l'horticulture, de la santé et de l'éducation aux niveaux local et mondial, en gardant à l'esprit que la biofortification et les compléments alimentaires, qui sont trop souvent perçus comme la seule solution, ne seront pas en mesure de faire face à ce double fardeau.

Dr. Jacky Ganry Directeur scientifique de Fruits 